\title{
Changes in fatty acid concentrations in tissues of African catfish, Clarias gariepinus Burchell, as a consequence of dietary carnitine, fat and lysine supplementation
}

\author{
R. O. A. Ozório*, J. L. A. Uktoseja, E. A. Huisman and J. A. J. Verreth \\ Fish Culture and Fisheries Group, Wageningen Institute of Animal Science (WIAS), \\ Wageningen University, P.O. Box 338, 6700 AH Wageningen, The Netherlands \\ (Received 29 January 2001 - Revised 2 July 2001 - Accepted 16 July 2001)
}

\begin{abstract}
A study was undertaken to examine the effect of different dietary carnitine $(200$ and $1000 \mathrm{mg} / \mathrm{kg}$ diet) and fat (90 and $190 \mathrm{~g} / \mathrm{kg}$ diet) supplementation on growth and fatty acid concentrations of fish fed either with a low- $(13 \mathrm{~g} / \mathrm{kg})$ or a high-lysine $(21 \mathrm{~g} / \mathrm{kg})$ diet. African catfish $(22.7 \mathrm{~g} / \mathrm{fish})$, Clarias gariepinus Burchell, juveniles were stocked (sixteen aquaria, twenty-five fish per aquarium) and fed for a maximum of $74 \mathrm{~d}$. Dietary lysine had a clear effect on growth performance and feed conversion ratios, but dietary carnitine supplements had no effect. Highcarnitine supplements increased total carnitine content $(P<0.0004)$ and reduced tissue free carnitine: acyl-carnitine ratio $(P<0.05)$ compared with low-carnitine supplements. High-fat supplements decreased liver carnitine concentrations. Clear effects on liver fatty acid concentrations were observed in high-carnitine-fed fish compared with low-carnitine-fed fish. The primary liver fatty acids affected were $18: 2 n-6$ (linoleic acid), $20: 5 n-3$ (eicosapentanoic acid) and $22: 6 n-3$ (docosahexanoic acid). The whole-body fatty acid balance suggested that $20: 5 n-3$ disappeared (apparently by $\beta$-oxidation) more readily than $18: 2 n-6$ and/or $22: 6 n-3$. From $774 \mathrm{mg} 20: 5 n-3$ eaten by high-lysine-high-fat-low-carnitine fish, $58 \%$ was not assimilated into body tissues. High-carnitine-fed fish showed an increase in $20: 5 n-3$ oxidation by $7 \%$ compared with low-carnitine fish. Although dietary carnitine did not improve body growth, these results support the hypothesis that carnitine can enhance the mobilisation of longchain fatty acids towards oxidation.
\end{abstract}

Carnitine: African catfish: Fatty acid balance: Lysine

Carnitine is synthesised in the liver from the amino acid lysine with methionine acting as a methyl donor (Broquist, 1997). It functions as a cofactor for the transport of fatty acids into the mitochondrial and thus facilitating the use of fatty acids for energy. Since total excretion rate of carnitine in mammals can reach 10.4 $\mu \mathrm{mol} / \mathrm{d}$ (Brooks \& McIntosh, 1975) and synthesis alone is not always sufficient (Cederblad \& Lindstedt, 1976) fatty acid oxidation may become impaired if carnitine and/or its precursors are not supplemented in the diet. According to Van Kempen \& Odle (1995) the capacity of fatty acid oxidation in neonatal pigs depends on dietary carnitine supplementation. Considering that carnitine supplements increase import of fatty acids into the mitochondria, it may be that carnitine can indirectly prevent protein from catabolism. Thus, animals fed diets with elevated carnitine and fat contents may have more protein energy available for growth. Early work of Bilinski \& Jonas (1970) indeed showed that free fatty acid oxidation by trout muscle mitochondria was highly activated by the addition of carnitine. In the past decade evidence was provided both to support and to reject this hypothesis. Rabie \& Szilagyi (1998) and Heo et al. (2000) also demonstrated that in broilers and piglets weight gain and fatty acid oxidation were improved by dietary carnitine. Gropp et al. (1994) showed that this effect, however, was more apparent when lysine and/or methionine were marginally present in quail. A number of studies in mammals have shown that lysine deficiency can diminish carnitine content of body tissue (Sachan \& Mynatt, 1993; Krajcovicova-Kudlackova et al. 2000). Effects of dietary carnitine on growth and lipid oxidation was also reported in several aquaculture species, e.g. African catfish (Clarias gariepinus Burchell), Red Sea

Abbreviations: FAME, fatty acid methyl ester; FCR, feed conversion ratio; HSI, hepatosomatic index; PUFA, polyunsaturated fatty acid; SGR, specific growth rate.

* Corresponding author: Dr Rodrigo Ozório, fax +31 317 483937, email Rodrigo_Ozorio@hotmail.com 
Table 1. Formulation of experimental diets

\begin{tabular}{|c|c|c|c|c|c|c|c|c|}
\hline & \multicolumn{4}{|c|}{ Low-lysine } & \multicolumn{4}{|c|}{ High-lysine } \\
\hline & \multicolumn{2}{|c|}{ Low-fat } & \multicolumn{2}{|c|}{ High-fat } & \multicolumn{2}{|c|}{ Low-fat } & \multicolumn{2}{|c|}{ High-fat } \\
\hline & Low carnitine & High carnitine & Low carnitine & High carnitine & Low carnitine & High carnitine & Low carnitine & High carnitine \\
\hline \multicolumn{9}{|l|}{ Ingredients $(\mathrm{g} / \mathrm{kg})^{*}$} \\
\hline Premix† & 25 & 25 & 25 & 25 & 25 & 25 & 25 & 25 \\
\hline Wheat meal & 131 & 131 & 209 & 209 & 466 & 466 & 400 & 400 \\
\hline Corn gluten meal & 180 & 180 & 308 & 308 & - & - & - & - \\
\hline Meat meal & - & - & - & - & 90 & 90 & 132 & 132 \\
\hline Blood meal & - & - & - & - & 17 & 17 & - & - \\
\hline Feather meal & 100 & 100 & 0 & 0 & 100 & 100 & 100 & 100 \\
\hline Menhaden meal & 150 & 150 & 150 & 150 & 150 & 150 & 150 & 150 \\
\hline Chalk & 83 & 81 & 79 & 77 & 67 & 65 & 56 & 54 \\
\hline Capelin oil & 55 & 55 & 120 & 120 & 55 & 55 & 106 & 106 \\
\hline Durabon binder & 26 & 26 & 24 & 24 & 25 & 25 & 25 & 25 \\
\hline Gelatinized cornstarch & 250 & 250 & 85 & 85 & - & - & - & - \\
\hline L-Lysine. $\mathrm{HCl}$ & - & - & - & - & 5 & 5 & 6 & 6 \\
\hline Carnikingł & - & 2 & _- & 2 & - & 2 & - & 2 \\
\hline Crude protein & 353 & 353 & 367 & 367 & 353.5 & 353.5 & 354.5 & 354.5 \\
\hline Crude fat & 90 & 90 & 190 & 190 & 90 & 90 & 190 & 190 \\
\hline Ash & 132 & 132 & 127 & 127 & $135 \cdot 5$ & $135 \cdot 5$ & 128 & 128 \\
\hline Carbohydrate§ & 372 & 372 & 257.5 & 257.5 & 374.5 & 374.5 & 275 & 275 \\
\hline Lysine & $13 \cdot 3$ & $13 \cdot 3$ & 13.8 & 13.8 & 21.8 & 21.8 & $22 \cdot 0$ & $22 \cdot 0$ \\
\hline Carnitine & 0.2 & 1.0 & 0.2 & 0.9 & 0.2 & 1.0 & 0.2 & 0.9 \\
\hline
\end{tabular}

* All ingredients, with exception of Carniking, and formulations were provided by Provimi (Rotterdam, The Netherlands).

†Contained (per kg mixture): Vitamin A $774 \mathrm{mg}$, vitamin D $6.35 \mathrm{~m}$, vitamin E $20000 \mathrm{mg}, \mathrm{CuSO}_{4} 501 \mathrm{mg}, \mathrm{ZnSO}_{4} 15000 \mathrm{mg}, \mathrm{MnSO}_{4} 0.001 \mathrm{mg}, \mathrm{CoSO}_{4} 500 \mathrm{mg}, \mathrm{KI}_{500} \mathrm{mg}_{2} \mathrm{Na}_{2} \mathrm{SeO}_{3} 35 \mathrm{mg}$.

$\neq$ Contained (g/kg): L-carnitine 500, silica 350, water 150 (Lonza Group Ltd, Basel, Switzerland).

§Carbohydrate data were estimated from the measured values of DM, crude protein, crude fat and ash according to: carbohydrate=DM-crude protein-crude fat-ash (modified by Cloet and Heinsbroek, unpublished results from Brafield, 1985). 
bream (Pagrus major), white prawn (Penaeus indicus) (Torreele et al. 1993; Chatzifotis et al. 1995; Jayaprakas \& Sambhu, 1996 respectively). In contrast to these studies, extra carnitine did not alter growth or body lipid composition in tilapia, salmonids, ornamental cichlid fish (Pelvicachromis pulcher) and hybrid striped bass, Morone chrysops female $\times M$-saxatilis male (Becker et al. 1999; Rodehutscord, 1995; Ji et al. 1996; Harpaz et al. 1999; Gaylord \& Gatlin, 2000). These difference of results between species suggest that the effects of dietary carnitine supplements are associated with different factors such as age and feed composition. In addition, metabolic requirements of the species under study may be important for occurence of the effect.

Similar to the study of Gropp et al. (1994), we hypothesised that growth and fatty acid concentrations of fish tissues are positively related to dietary carnitine levels. Carnitine supplementation is expected to increase fatty acid oxidation and as a result protein:fat ratio in African catfish body will increase. In addition, one may expect that nutritional conditions, which give decreased carnitine synthesis, e.g. dietary lysine deficiency, will enhance the effect of dietary carnitine.

Since in the effects of carnitine on metabolism and concentration of long-chain fatty acids is most obvious, we decided to study $\mathrm{C}_{14}-\mathrm{C}_{22}$, as defined by Odle (1997), in tissues of the African catfish.

\section{Material and methods}

\section{Experimental animals and husbandry}

This experiment was approved by the Dutch Experimental Animal and Welfare Committee according to the EC Directive applied to vertebrate animals.

African catfish $(10 \mathrm{~g})$ were obtained from a Dutch commercial catfish hatchery (Fleuren, Someren, The Netherlands). All fish were full siblings and had an identical nutritional history.

The experiment was conducted at the experimental facilities of the Fish Culture and Fisheries Group, Wageningen Institute of Animal Science (WIAS), Wageningen-UR. After arrival, the fish were equally distributed over four aquaria at a density of approximately 230 fish per 70 litre aquarium. The animals were allowed acclimatisation to the recirculation system conditions for 1 week. During this acclimatisation week, fish were fed on a lowcarnitine-low-lysine-low-fat diet at a feeding rate of $24 \mathrm{~g} / \mathrm{kg}^{0.8}$ per $\mathrm{d}$.

After acclimatisation, fish of uniform size $(22.7 \mathrm{~g})$ were randomly assigned to each of sixteen aquaria, twenty-five fish per aquarium. The aquaria used were glass aquaria $(70 \times 35 \times 40 \mathrm{~cm})$ with a 90 litre capacity, filled to 70 litres, and a $25 \%$ refreshment once per week. Each aquarium was connected to a recirculation system with capacity of $8.25 \mathrm{~m}^{3}$ water, and checked daily for dead fish. The flow

Table 2. Fatty acid concentrations of experimental diets (mg/g diet DM)

\begin{tabular}{|c|c|c|c|c|}
\hline & \multicolumn{2}{|c|}{ Low-lysine } & \multicolumn{2}{|c|}{ High-lysine } \\
\hline & $\begin{array}{c}\text { Low-fat } \\
\text { Low-high-carnitine }\end{array}$ & $\begin{array}{c}\text { High-fat } \\
\text { Low-high-carnitine }\end{array}$ & $\begin{array}{c}\text { Low-fat } \\
\text { Low-high-carnitine }\end{array}$ & $\begin{array}{c}\text { High-fat } \\
\text { Low-high-carnitine }\end{array}$ \\
\hline \multicolumn{5}{|l|}{ Fatty acids } \\
\hline $14: 0$ & 3.00 & 4.91 & 2.79 & $4 \cdot 87$ \\
\hline $16: 0$ & $9 \cdot 38$ & $16 \cdot 83$ & $10 \cdot 35$ & $17 \cdot 34$ \\
\hline $18: 0$ & $1 \cdot 76$ & $2 \cdot 78$ & $2 \cdot 76$ & $4 \cdot 07$ \\
\hline $16: 1^{*}$ & 3.00 & 4.95 & $2 \cdot 35$ & $5 \cdot 08$ \\
\hline $18: 1 n-9$ & $7 \cdot 55$ & 14.55 & $6 \cdot 65$ & $14 \cdot 76$ \\
\hline $18: 1 n-7$ & $1 \cdot 21$ & 2.07 & $1 \cdot 12$ & $2 \cdot 21$ \\
\hline $20: 1 \dagger$ & $3 \cdot 40$ & 5.90 & $2 \cdot 71$ & $5 \cdot 43$ \\
\hline $22: 1 \ddagger$ & $4 \cdot 80$ & $8 \cdot 76$ & 3.92 & 8.06 \\
\hline $18: 2 n-6$ & $4 \cdot 81$ & $8 \cdot 87$ & 4.90 & $4 \cdot 49$ \\
\hline $18: 3 n-3$ & 0.64 & $1 \cdot 22$ & 0.40 & $1 \cdot 06$ \\
\hline $18: 4 n-3$ & $1 \cdot 23$ & $2 \cdot 11$ & 0.90 & 1.91 \\
\hline $20: 5 n-3$ & $4 \cdot 67$ & $7 \cdot 80$ & 3.90 & $7 \cdot 14$ \\
\hline $22: 5 n-3$ & 0.54 & 0.88 & 0.30 & 0.82 \\
\hline $22: 6 n-3$ & $5 \cdot 58$ & $11 \cdot 32$ & $5 \cdot 20$ & $10 \cdot 28$ \\
\hline$\Sigma$ SFA§ & 14.58 & $25 \cdot 36$ & $16 \cdot 38$ & $27 \cdot 17$ \\
\hline$\Sigma$ MUFA\| & $20 \cdot 27$ & $36 \cdot 87$ & $17 \cdot 04$ & $36 \cdot 16$ \\
\hline$\Sigma n-6$ PUFAף & $5 \cdot 36$ & $9 \cdot 78$ & $5 \cdot 33$ & $5 \cdot 42$ \\
\hline$\sum n-3$ PUFA** & $13 \cdot 14$ & $24 \cdot 24$ & $10 \cdot 95$ & $22 \cdot 07$ \\
\hline$\Sigma$ LCFA†† & 53.35 & $96 \cdot 25$ & $49 \cdot 7$ & $90 \cdot 82$ \\
\hline$\sum n-3 / \sum n-6$ & 2.45 & 2.48 & 2.05 & 4.07 \\
\hline $\begin{array}{l}\text { SFA, saturated } \\
\text { acid. } \\
\text { * Predominantly } \\
\text { †Includes } 20: 1 \\
\text { † Includes } 22: n \\
\text { § Includes } 15: 0 \\
\text { II Includes } 14: 1 \text { ' } \\
\text { I Includes } 16: 3 \\
\text { ** Includes } 16: 3 \\
\text { †† } \mathrm{C}_{14}-\mathrm{C}_{22} \text { as d }\end{array}$ & $\begin{array}{l}\text { acid; MUFA, monouns } \\
1 n-7 . \\
20: 1 n-9 \text { and } 20: 1 n-7 \\
22: 1 n-11 \text { and } 22: 1 n-9 \\
17: 0 . \\
15: 1 n-3 \text { and } 18: 1 n-5 \text {. } \\
\text { and } 20: 3 n-6 . \\
18: 2 n-3 \text { and } 20: 4 n-3 \text {. } \\
\text { ed by Odle (1997). }\end{array}$ & rated fatty acids; PUFA & olyunsaturated fatty acic & LCFA, long-chain fatty \\
\hline
\end{tabular}


rate $(61 / \mathrm{min})$, water temperature $\left(27 \pm 0 \cdot 05^{\circ} \mathrm{C}\right), \mathrm{pH}$ (7.03 \pm 0.38$)$, dissolved $\mathrm{O}_{2}(>5 \mathrm{mg} / \mathrm{l})$ and conductivity $(6.07 \pm 0.06 \mathrm{mS} / \mathrm{cm})$ were checked daily. $\mathrm{NH}_{4}(0.4 \pm$ $0 \cdot 1 \mathrm{mg} / 1), \mathrm{NO}_{3}(174 \pm 29 \mathrm{mg} / \mathrm{l})$ and $\mathrm{NO}_{2}(0 \cdot 2 \pm 0 \cdot 2 \mathrm{mg} / \mathrm{l})$ were checked once per week. Fish were kept under a $12 \mathrm{~h}$ light-dark cycle. In case of mortality, fish were removed and daily feed amount was adjusted to the remaining number.

\section{Diets, feeding and design}

The eight experimental diets contained a lysine level of 13 or $21 \mathrm{~g} / \mathrm{kg}$, one of two levels of fat (90 and $190 \mathrm{~g} / \mathrm{kg}$ ), and one of two levels of carnitine $(0.2$ and $1.0 \mathrm{~g} / \mathrm{kg})$ in a $2 \times 2 \times 2$ factorial design (Table 1). All diets were isonitrogeneous ( $350 \mathrm{~g}$ crude protein $/ \mathrm{kg}$ ) and close to isoenergetic (about $18 \mathrm{~g}$ crude protein/ $\mathrm{kJ}$ gross energy). Low-carnitine and low-lysine diets were formulated using a combination of wheat meal and corn gluten as the primary protein source. Two levels of dietary lysine and carnitine were selected to represent the below-requirement level and the above-requirement level for catfish (Robinson et al. 1980; Torreele et al. 1993). Fat levels were set at the outer margins of the accepted inclusion range for African catfish (Uys, 1989).

Carniking ${ }^{\circledR}$ (Lonza Group Ltd, Basel, Switzerland) and L-lysine $\mathrm{HCl}$ ingredients were added to each diet by premixing the respective quantities in the premix prior to extrusion. The ingredients were mixed, extruded using co-rotating screw extruder (APV-Baker, Newcastle, UK) into $2.24 \mathrm{~mm}$ diameter $\times 5 \mathrm{~mm}$ length pellets and air-dried to $50 \mathrm{~g}$ moisture $/ \mathrm{kg}$. The floating diets were fed to fish slowly, in small amounts by hand, two times per day (09.00 and 17.00 hours) at a feeding level of $24 \mathrm{~g} / \mathrm{kg}^{08}$ per $\mathrm{d}, 7 \mathrm{~d}$ per week. The appetite of the fish was monitored carefully to minimise wastage of food. It was relatively easy to detect the point at which the catfish ceased active feeding from their behaviour since they stop agitating against the water surface and move away from the feeding area of the aquarium. Each feeding lasted about 4 min per aquarium. To obtain the same total feed intake, low-lysine groups were allowed more feeding days. Thus, the experimental sampling was designed in two periods (53 and $74 \mathrm{~d}$ ).

Diets were analysed for proximate composition and fatty acid concentrations (Table 2) prior to the experiment. Treatments were tested in duplicate aquaria and fish were fed till a total feed intake of $120 \mathrm{~g}$ feed/fish was realised.

\section{Sample collection, storage and analytical techniques}

Two days before tissue sampling, twelve fish were taken from each treatment, killed by overdose of tricaine methane sulphonate $(0 \cdot 3 \mathrm{~g} / \mathrm{l}$; Crescent Research Chemicals, Phoenix, $\mathrm{AZ}, \mathrm{USA})$ and $\mathrm{NaHCO}_{3}(0.4 \mathrm{~g} / \mathrm{l})$ and weighed individually to the nearest $0 \cdot 1 \mathrm{~g}$. Growth performance and feed conversion were measured from these animals in terms of percentage weight gain (specific growth rate, SGR), feed conversion ratio (FCR) and hepatosomatic index (HSI). Growth response parameters were calculated as follows: $\operatorname{SGR}(\% / \mathrm{d})=\left(\left(\ln W_{f}-\ln W_{0}\right) / \mathrm{t}\right) \times 100$ where $W_{f}$ is the weight of fish at time $t(t=53$ or $74 \mathrm{~d}), W_{0}$ is the weight of fish at time $0 ; \mathrm{FCR}=$ total dry feed fed $(\mathrm{g}) /$ total wet weight gain $(\mathrm{g})$; and $\mathrm{HSI}=$ wet weight liver $(\mathrm{g}) /$ wet weight fish $(\mathrm{g}) \times 100$. Proximate compositions and fatty acid concentration were measured from tissues (whole-body, liver and muscle) removed from fifteen fish from each aquarium deprived of food for $24 \mathrm{~h}$ prior to sampling. Tissues were pooled by aquarium, and immediately stored at $-20^{\circ} \mathrm{C}$. Frozen muscle samples were cut without thawing into pieces avoiding drip losses, minced using a meat mincer and pooled homogeneously. Frozen liver samples were homogenised using an Ultra Torax grinder (Janke \& Kunkel $\mathrm{GmbH}$, Staufen, Germany). After homogenisation, part of each sample was again frozen immediately and freeze-dried to eliminate water interference during certain analyses.

In brief, approximately $100 \mathrm{~g}$ sample was placed into the freeze-dryer (FTS system Inc., Stoneridge, NY, USA) and kept under a pressure of $26 \mathrm{~Pa}$ and a condenser temperature of $-85^{\circ} \mathrm{C}$. The shelf temperature was raised gradually during the freeze-drying process over $36 \mathrm{~h}$ from $-20^{\circ} \mathrm{C}$ to room temperature. A small sample from each batch was further dried using the standard DM determination (ISO 6496 (International Organization for Standardization, 1983) to evaluate the water content of the freeze-dried material.

After freeze-drying, muscle samples were powdered using a foodstuff mincer (Retsch ZM $100 \mathrm{GmbH}$, Haan, Germany) and again homogenised. Because of high levels of fat in the liver samples, it was not possible to homogenise them using the foodstuff mincer. Instead, the freeze-dried liver was homogenised using a coffee grinder.

DM was determined by drying the samples for $4 \mathrm{~h}$ at $103^{\circ} \mathrm{C}$ (ISO 6496 (International Organization for Standardization, 1983)) and ash content was measured by ashing the samples for $4 \mathrm{~h}$ at $550^{\circ} \mathrm{C}$ (ISO 5984 (International Organization for Standardization, 1978)). Crude protein was measured by Kjeldahl according to ISO 5983 (International Organization for Standardization, 1978) procedures and calculated as $\mathrm{N}$ content multiplied by 6.25. Crude fat was determined by Soxhlet extraction (EEG 18.1.84 no. 15/29-30). Gross energy was measured by bomb calorimetry (IKA-C-7000; Fa. IKA-Analysentechnik, Weitersheim, Germany), and fatty acids were measured in duplicate from freeze-dried sample by high resolution GC according to a modified procedure of Lepage \& Roy (1984). DM matter, ash, and protein analyses were done from fresh sample of muscle and liver tissues in triplicate and in duplicate respectively. Fat and energy analyses were done from freeze-dried material in duplicate and triplicate respectively. Carnitine determination was performed from freeze-dried material by radiometric detection of free- and acyl-carnitine following the procedure of Christiansen \& Bremer (1988).

\section{Fatty acid analysis}

Fatty acid methyl ester (FAME) analysis from liver and muscle tissues was performed using a high resolution GC method, employing capillary columns and flame ionisation detection, fitted with an automatic split type injection $1 \mu 1: 20 \mu 1$ (type SSL 71; Fison Instruments, Milano, Italy). A small amount $(0.2 \mathrm{~g})$ sample was saponified and transesterified with methanolic $\mathrm{KOH}$ and the methyl esters 
extract into hexane according to a modified direct transesterification technique as described by Lepage \& Roy (1984). Tricosanoic acid methyl ester (23:0; Sigma T9900, Sigma, St Louis, MO, USA) was used as internal standard because it is a stable fatty acid, not present in fish tissue and therefore can be easily identified during chromatography. Injection of $1 \mu \mathrm{l}$ was performed in high resolution Mega 2 Series (Fison Instruments), fitted with a $30 \mathrm{~m} \times 0.25 \mathrm{~mm}$ i.d. column silicate type and $0.25 \mu \mathrm{m}$ DBWAX film 122-7032; J\&W Scientific, Folsom, USA). Detector type was the flame ionisation detector and the carrier gas was He with a flow rate of $2 \mathrm{ml} / \mathrm{min}$. The oven was programmed to start at $80^{\circ} \mathrm{C}$, rising $5^{\circ} \mathrm{C} / \mathrm{min}$ until $140^{\circ} \mathrm{C}$ and then $2^{\circ} \mathrm{C} / \mathrm{min}$ until $200^{\circ} \mathrm{C}$. Thereafter, it rose $1^{\circ} \mathrm{C} / \mathrm{min}$ to the final temperature of $250^{\circ} \mathrm{C}$. The injection and detector temperatures were $200^{\circ} \mathrm{C}$ and $250^{\circ} \mathrm{C}$ respectively. Peak identification and quantification was done by using the relative retention times between each FAME from diet or tissue and the reference standards for the most common FAME (Sigma kit no. 189-19; Sigma). These include $14: 0$, $14: 1 n-5,15: 0,15: 1 n-5, \quad 16: 0,16: 1 n-7,17: 0$, $17: 1 n-7,18: 0,18: 1 n-9,18: 2 n-6,18: 3 n-3,18: 3 n-6$, $20: 0,20: 1 n-9,20: 2 n-6,20: 3 n-3,20: 3 n-6,20: 4 n-6$, $20: 5 n-3,21: 0,22: 0,22: 1 n-9,22: 2 n-6,22: 6 n-3$, $23: 0,24: 0$ and $24: 1 n-9$. The results are expressed as FAME and only main FAME are presented. Integration was done by using Chrom-card for Windows, version 1.17 (Fisons Instruments).

Fatty acid balance was calculated assuming no faecal losses of the fatty acids. Therefore, the difference between fatty acid intake and its accumulation in fish body equals their disappearance (apparent oxidation) (Cunnane \& Yang, 1995).

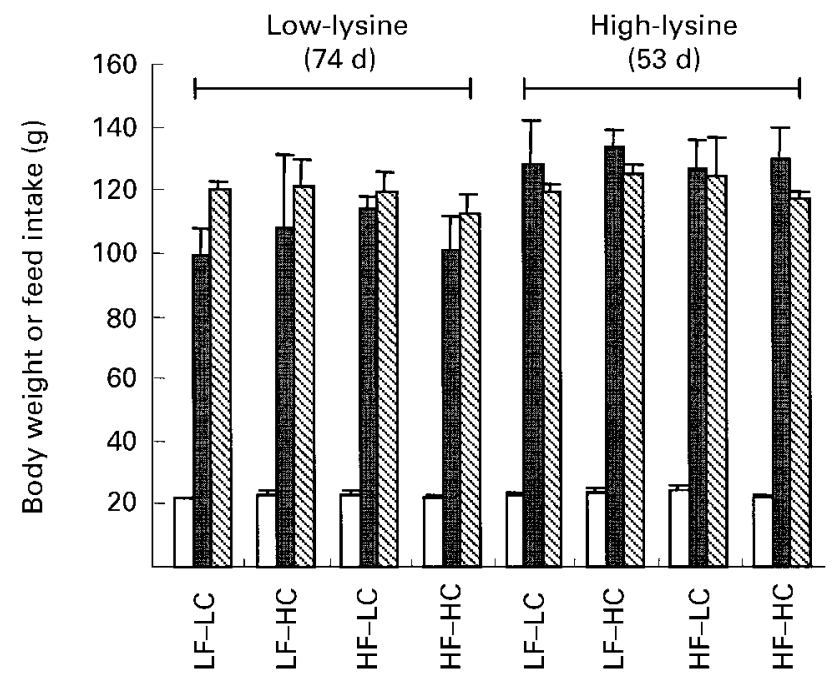

Fig. 1. Effect of feeding different experimental diets on body weight and feed intake of African catfish (Clarias gariepinus Burchell). For details of diets and procedures, see Tables 1 and 2. LF, low-fat; HF, high-fat; LC, low-carnitine; HC, high-carnitine. $\square$, Initial weight; 口, final weight; , feed intake. Values are means for two aquaria per treatment with twelve fish per treatment, with standard deviations shown by vertical bars.

\section{Statistical analysis}

Results are reported as mean values and standard deviations per treatment unless otherwise stated. Normality was tested using Shapiro-Wilk test. Homogeneity was checked using the absolute residuals according to Levene's test. Nonhomogeneous data were arcsine transformed prior to further
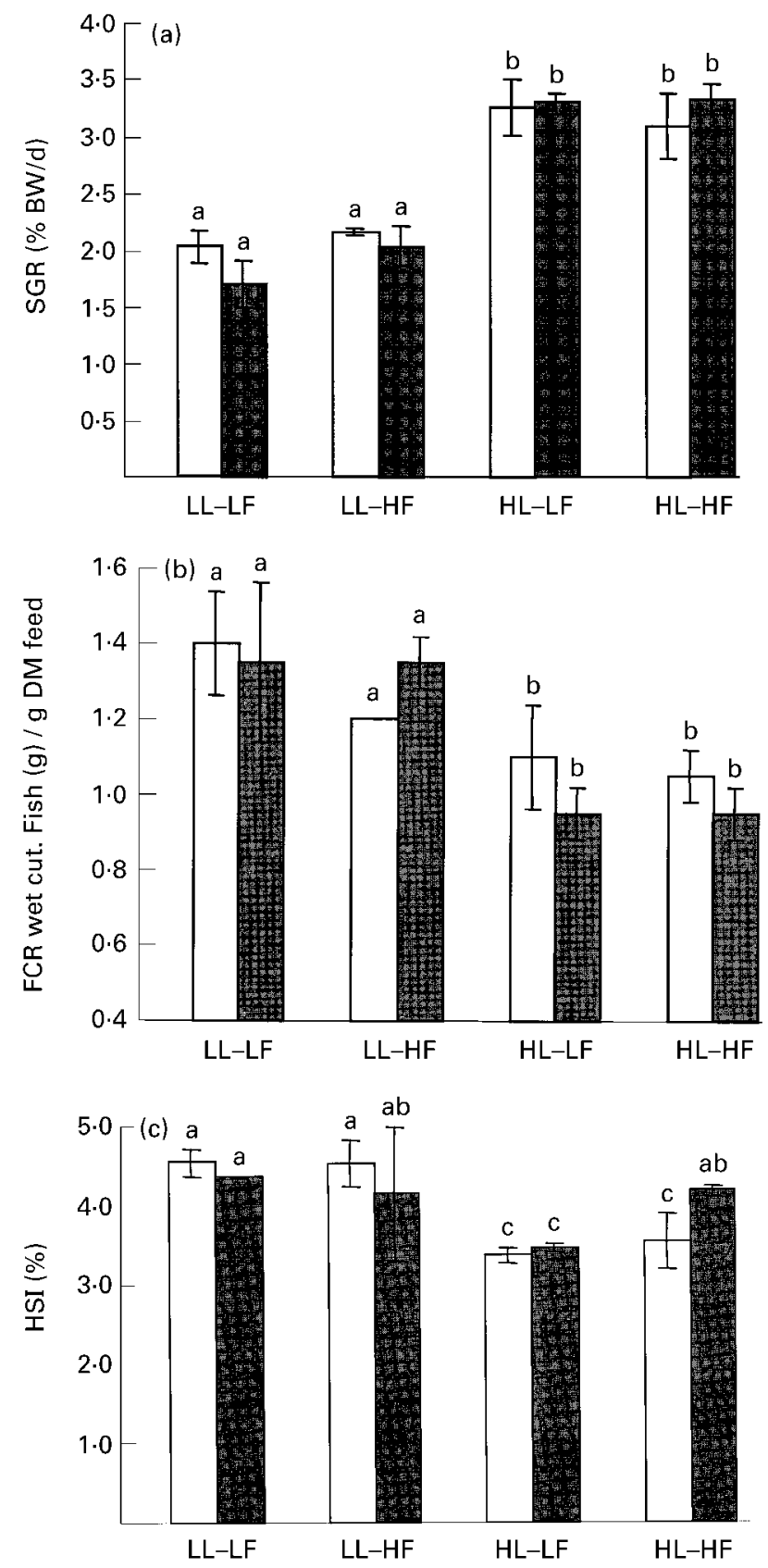

Fig. 2. Effect of feeding different experimental diets on (a) specific growth rate (SGR), (b) feed conversion ratio (FCR) and (c) hepatosomatic index (HSI) of African catfish (Clarias gariepinus Burchell). For details of diets and procedures, see Tables 1 and 2 and p. 626. LL, low-lysine; HL, high-lysine; LF, low-fat; HF, high-fat; BW, body weight. $\square$, Low-carnitine; $\mathbf{\square}$, high-carnitine. Values are means for two aquaria per treatment with twelve fish per treatment, with standard deviations shown by vertical bars. ${ }^{a, b, c}$ Mean values with unlike superscript letters were significantly different (ANOVA, $P<0.05$ ). 
statistical analysis. Proximate analysis, FAME analysis and growth data were subjected to the three-way ANOVA according to the model:

$$
\begin{aligned}
\mathrm{Y}_{\mathrm{ijkl}}= & \mu+\mathrm{Car}_{\mathrm{i}}+\mathrm{Lys}_{\mathrm{j}}+\mathrm{Fat}_{\mathrm{k}}+(\text { Lys } \times \text { Car })_{\mathrm{ji}}+(\mathrm{Lys} \\
& \times \text { Fat })_{\mathrm{jk}}+(\text { Car } \times \text { Fat })_{\mathrm{ik}}+(\text { Car } \times \text { Lys } \times \text { Fat })_{\mathrm{ijk}} \\
& +\mathrm{e}_{\mathrm{ijkl}},
\end{aligned}
$$

where $\mathrm{Y}_{\mathrm{ijkl}}$ corresponds to the growth performance, tissue proximate composition, carnitine content or fatty acid concentrations, Car $_{i}$ relates to the dietary carnitine effect, Lys $_{j}$ to the dietary lysine effect, Fat ${ }_{k}$ to the dietary fat effect, $(\text { Lys } \times \text { Car })_{j i}$ to the lysine-carnitine interaction effect, $(\text { Lys } \times \text { Fat })_{j k}$ to the lysine - fat effect; $(\text { Car } \times \text { Fat })_{i k}$ to the carnitine-fat effect; (Car $\times$ Lys $\times$ Fat $)_{i j k}$ to the carnitine-lysine-fat interaction, and $\mathrm{e}_{\mathrm{ijkl}}$ represents the error term.

Differences between means were reported as significant if $P<0 \cdot 05$. All statistical analyses were performed using SAS program (Version 6, 1990; Statistical Analysis Systems Inc., Cary, NC, USA).

\section{Results \\ Growth and proximate composition}

The average cumulative mortality during the experiment was $<5 \%$. Fish grew from a mean initial weight of $22.7 \mathrm{~g}$ to final weights of $105.5 \mathrm{~g}$ for low-lysine groups $(74 \mathrm{~d})$ and to $129.5 \mathrm{~g}$ for high-lysine groups (53 d) (Fig. 1). This gain coincides with a SGR of $2.3 \%$ body weight/d for low-lysine groups and $3.3 \%$ body weight/d for high-lysine group (Fig. 2). Differences in SGR were also reflected in FCR, which averaged $1.0 \mathrm{~g} / \mathrm{g}$ in high-lysine groups and $1.5 \mathrm{~g} / \mathrm{g}$ in low-lysine groups (Fig. 2). Dietary carnitine supplements showed no significant effect on the HSI (Fig. 2, $P>0.05$ ). High-lysine diets highly improved SGR and decreased FCR $(P<0 \cdot 001)$. Fish receiving low-lysine diets showed higher HSI than fish fed the high-lysine diets $(P<0 \cdot 01)$. Dietary fat supplements showed no apparent effect on growth rates and no interaction whatsoever was observed.

Tissue composition of catfish at the end of the growth experiment varied in crude fat and crude protein contents (Fig. 4). Protein:fat ratio was reduced in all tissues studied as a consequence of high dietary fat supplements $(P<0 \cdot 05)$. Dietary low-lysine supplements also increased body fat contents compared with dietary high-lysine supplements. Dietary carnitine supplements significantly affected whole-body and liver fat content only in lowlysine-low-fat groups.

\section{Tissue carnitine composition}

Overall, carnitine content in tissues were positively related to dietary carnitine level $(P<0 \cdot 001$, Fig. 3). High-carnitine fed fish showed about a 3.5-fold increase in carnitine content over the low-carnitine groups $(P<0 \cdot 001)$. Liver contents of both free- and acyl-carnitine esters were approximately forty times lower than the carnitine contents of the muscle tissue and fifteen times lower than the contents of the whole body. Fish fed low-lysine diets showed lower liver free-carnitine concentration than high-lysine animals $(P<0 \cdot 01)$. High-fat supplements also reduced liver carnitine. A lysine $v$. carnitine interaction was observed $(P<0 \cdot 01)$, but a carnitine $v$. fat interaction was not observed.

\section{Fatty acid concentration}

Effects of dietary carnitine, fat and lysine supplements on fatty acid concentration of the liver and the muscle tissues are shown in Tables 3 and 4 respectively, and the statistical significance is represented in Table 5. Muscle total fatty acids concentration ranged from 271 to $335 \mathrm{mg} / \mathrm{kg}$ (Table 3 ). Muscle $n-3$ and $n-6$ long-chain polyunsaturated fatty acids (PUFA) concentrations were slightly affected after $74 \mathrm{~d}$ by high-carnitine intake $(P<0 \cdot 1)$. The principal fatty acid affected was docosahexanoic acid (22:6n-3). The effect of carnitine on muscle fatty acid concentrations were observed only when fish were offered the low-lysine-low-fat diets.
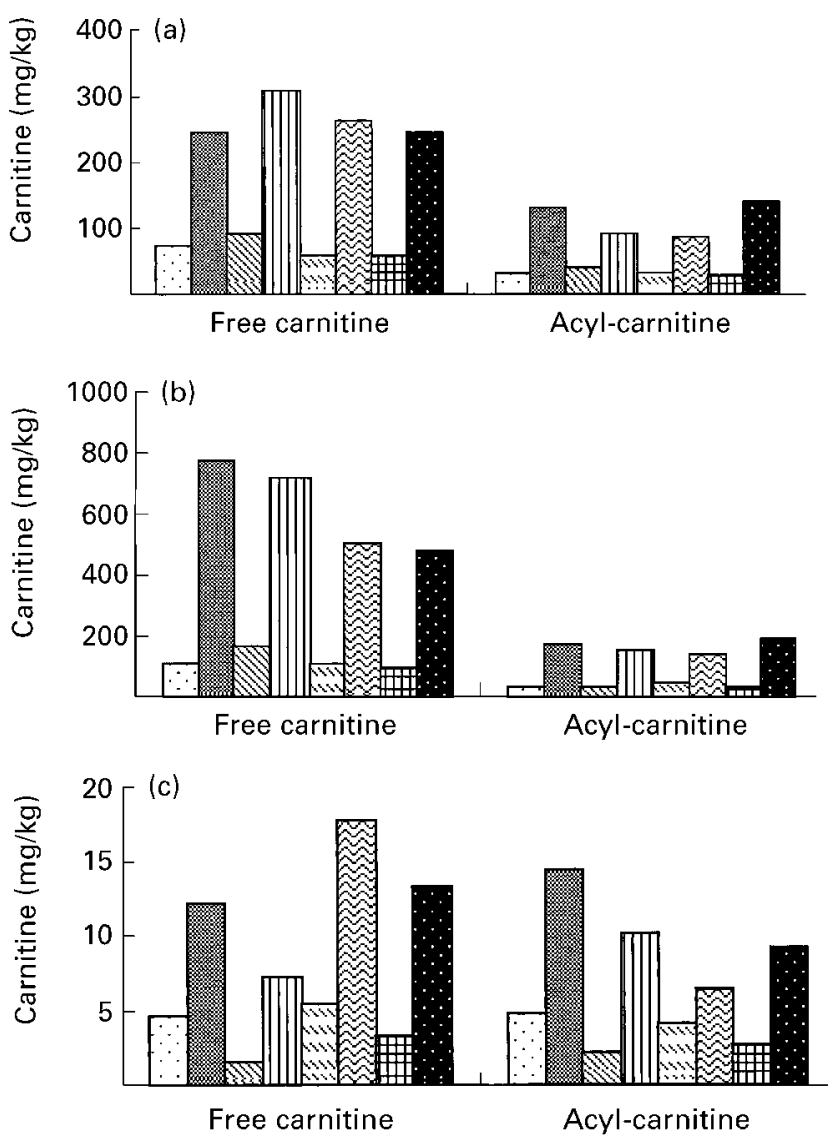

Fig. 3. Effect of dietary carnitine supplements on free- and acylcarnitine content in African catfish (Clarias gariepinus Burchell) (a) Whole-body; (b) muscle tissue; (c) liver. For details of diets and procedures, see Tables 1 and 2 and p. 626. ๑, Lowlysine-low-fat-low-carnitine; 圈, low-lysine-low-fat-high-carnitine; \&, low-lysine-high-fat-low-carnitine; $\mathbb{m}$, low-lysine-high-fat-highcarnitine; $⿴ 囗 \mathrm{~g}$, high-lysine-low-fat-low-carnitine; 圈, high-lysinelow-fat-high-carnitine; 田, high-lysine-high-fat-low-carnitine; $\mathbf{\Xi}$, high-lysine-high-fat-high-carnitine. Values are means for two aquaria per treatment with fifteen fish per aquarium. 
Table 3. Fatty acid concentrations of muscle total lipids ( $\mathrm{mg} / \mathrm{g}$ tissue DM)*

(Mean values and standard deviations of two aquaria per treatment with fifteen fish per aquarium)

\begin{tabular}{|c|c|c|c|c|c|c|c|c|c|c|c|c|c|c|c|c|}
\hline & \multicolumn{8}{|c|}{ Low-lysine } & \multicolumn{8}{|c|}{ High-lysine } \\
\hline & \multicolumn{4}{|c|}{ Low-fat } & \multicolumn{4}{|c|}{ High-fat } & \multicolumn{4}{|c|}{ Low-fat } & \multicolumn{4}{|c|}{ High-fat } \\
\hline & \multicolumn{2}{|c|}{ Low-carnitine } & \multicolumn{2}{|c|}{ High-carnitine } & \multicolumn{2}{|c|}{ Low-carnitine } & \multicolumn{2}{|c|}{ High-carnitine } & \multicolumn{2}{|c|}{ Low-carnitine } & \multicolumn{2}{|c|}{ High-carnitine } & \multicolumn{2}{|c|}{ Low-carnitine } & \multicolumn{2}{|c|}{ High-carnitine } \\
\hline & Mean & SD & Mean & SD & Mean & SD & Mean & SD & Mean & SD & Mean & SD & Mean & SD & Mean & SD \\
\hline \multicolumn{17}{|l|}{ Fatty acids } \\
\hline $14: 0$ & $10 \cdot 20$ & 0.40 & 10.58 & 0.09 & 13.44 & 0.85 & $12 \cdot 11$ & 1.01 & $11 \cdot 72$ & 0.71 & 11.47 & 0.07 & $13 \cdot 88$ & 0.47 & 12.90 & 0.21 \\
\hline $16: 0$ & 87.95 & $5 \cdot 81$ & $82 \cdot 72$ & $1 \cdot 86$ & 82.48 & 0.22 & $77 \cdot 84$ & $3 \cdot 16$ & $71 \cdot 26$ & 3.59 & $70 \cdot 16$ & 0.82 & 69.50 & 0.54 & 69.66 & 0.16 \\
\hline $18: 0$ & 18.62 & 1.50 & $19 \cdot 40$ & $0 \cdot 16$ & $20 \cdot 81$ & 0.46 & $20 \cdot 29$ & 1.59 & $19 \cdot 15$ & $1 \cdot 21$ & $19 \cdot 92$ & 0.07 & $20 \cdot 06$ & 0.34 & 19.00 & 0.26 \\
\hline $16: 1 \dagger$ & $15 \cdot 46$ & 0.82 & $17 \cdot 70$ & 0.26 & $17 \cdot 29$ & 0.62 & $16 \cdot 17$ & 0.88 & 16.04 & 0.96 & 14.81 & 0.13 & $16 \cdot 39$ & 0.64 & $16 \cdot 15$ & 0.23 \\
\hline $18: 1 n-9$ & $62 \cdot 02$ & 1.99 & 62.52 & $4 \cdot 26$ & 65.55 & 0.30 & $61 \cdot 82$ & $7 \cdot 27$ & $61 \cdot 26$ & $4 \cdot 37$ & $59 \cdot 31$ & 0.04 & $58 \cdot 88$ & 0.63 & 59.43 & 0.00 \\
\hline $18: 1 n-7$ & 5.94 & $0 \cdot 16$ & 6.49 & 0.03 & 6.39 & 0.07 & 6.08 & 0.45 & 6.36 & 0.02 & 6.35 & 0.04 & 7.04 & 0.15 & 6.68 & 0.21 \\
\hline $20: 1 \ddagger$ & 10.96 & 0.30 & 11.79 & 0.02 & 14.50 & 0.38 & $13 \cdot 20$ & 0.86 & $12 \cdot 33$ & 0.08 & $12 \cdot 31$ & 0.29 & 14.41 & 0.47 & 13.66 & 0.40 \\
\hline $22: 1 \S$ & 6.99 & 0.67 & 7.40 & 0.14 & $10 \cdot 60$ & 0.19 & $9 \cdot 19$ & 0.50 & $8 \cdot 19$ & 0.27 & $8 \cdot 39$ & 0.03 & 12.04 & 0.40 & $10 \cdot 84$ & 0.68 \\
\hline $18: 2 n-6$ & 18.43 & 0.47 & $20 \cdot 66$ & 0.16 & 33.01 & $1 \cdot 80$ & 28.83 & $2 \cdot 84$ & 18.80 & 0.58 & 18.58 & 0.15 & $18 \cdot 81$ & 0.33 & 17.65 & 0.10 \\
\hline $20: 2 n-6$ & 0.99 & 0.04 & 0.94 & 0.03 & 1.22 & 0.04 & $1 \cdot 18$ & 0.12 & 0.81 & 0.05 & 0.82 & 0.02 & 0.91 & 0.04 & 0.88 & 0.04 \\
\hline $20: 4 n-6$ & 1.03 & 0.03 & $1 \cdot 21$ & 0.04 & $1 \cdot 38$ & 0.06 & 1.33 & 0.01 & 1.03 & 0.06 & 1.07 & 0.04 & 1.27 & 0.00 & $1 \cdot 21$ & 0.02 \\
\hline $18: 3 n-3$ & 1.84 & $0 \cdot 12$ & $2 \cdot 12$ & 0.01 & 3.50 & 0.30 & 2.98 & 0.28 & 2.59 & 0.00 & 2.54 & 0.01 & 3.35 & 0.09 & 3.04 & 0.15 \\
\hline $18: 4 n-3$ & $2 \cdot 17$ & 0.44 & 2.69 & 0.01 & 4.05 & 0.38 & 3.29 & 0.29 & 2.93 & 0.04 & $2 \cdot 80$ & 0.01 & $4 \cdot 36$ & 0.13 & $3 \cdot 71$ & 0.29 \\
\hline $20: 5 n-3$ & $7 \cdot 21$ & 0.91 & 8.65 & 0.24 & $13 \cdot 28$ & $1 \cdot 12$ & $10 \cdot 73$ & 0.86 & $9 \cdot 29$ & 0.08 & $9 \cdot 39$ & $0 \cdot 10$ & $14 \cdot 20$ & 0.04 & $12 \cdot 06$ & 0.20 \\
\hline $22: 5 n-3$ & $2 \cdot 33$ & $0 \cdot 11$ & $2 \cdot 87$ & 0.03 & 3.66 & $0 \cdot 15$ & $3 \cdot 16$ & 0.25 & $2 \cdot 87$ & $0 \cdot 10$ & 3.01 & 0.01 & 3.63 & 0.21 & $3 \cdot 41$ & 0.09 \\
\hline $22: 6 n-3$ & $19 \cdot 23$ & 0.78 & 24.53 & 0.47 & 34.19 & 1.93 & 32.00 & 1.93 & $22 \cdot 24$ & 0.27 & $22 \cdot 17$ & 0.37 & $30 \cdot 88$ & 1.40 & $29 \cdot 32$ & 1.53 \\
\hline$\Sigma$ SFA & 118.43 & 4.74 & 114.39 & $2 \cdot 11$ & 119.08 & $1 \cdot 17$ & $112 \cdot 26$ & $5 \cdot 83$ & $104 \cdot 22$ & 5.58 & $103 \cdot 70$ & 0.70 & $106 \cdot 21$ & 1.40 & 104.05 & 0.88 \\
\hline$\Sigma$ MUFAף & $102 \cdot 52$ & $2 \cdot 63$ & $107 \cdot 14$ & 3.89 & $116 \cdot 15$ & 1.50 & $108 \cdot 12$ & $10 \cdot 07$ & 105.59 & 5.72 & $102 \cdot 64$ & 0.48 & $110 \cdot 74$ & 1.09 & 108.57 & 1.24 \\
\hline$\Sigma n-6$ PUFA $^{* *}$ & $22 \cdot 79$ & $0 \cdot 28$ & $25 \cdot 33$ & 0.14 & 38.32 & 2.03 & $33 \cdot 86$ & 3.30 & $22 \cdot 78$ & 0.87 & $22 \cdot 37$ & 0.12 & $22 \cdot 77$ & 0.35 & 21.53 & 0.00 \\
\hline$\Sigma n$-3 PUFA†† & 34.69 & 0.66 & 42.95 & 0.24 & $61 \cdot 72$ & 4.07 & 54.95 & $3 \cdot 80$ & $42 \cdot 28$ & 0.54 & $42 \cdot 34$ & 0.52 & 59.54 & 1.84 & 54.5 & 2.42 \\
\hline 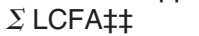 & 278.43 & $2 \cdot 66$ & $289 \cdot 81$ & 5.99 & $335 \cdot 27$ & $7 \cdot 73$ & $309 \cdot 19$ & $21 \cdot 13$ & 274.87 & 44.33 & 271.05 & 11.75 & $299 \cdot 26$ & 3.65 & 288.65 & 2.94 \\
\hline$\Sigma n-3 / \Sigma n-6$ & 1.52 & 0.01 & 1.70 & 0.02 & 1.61 & 0.02 & 1.62 & 0.05 & 1.86 & 0.05 & 1.89 & 0.01 & 2.62 & 0.04 & 2.53 & 0.11 \\
\hline
\end{tabular}

SFA, saturated fatty acid; MUFA, monounsaturated fatty acids; PUFA, polyunsaturated fatty acids; LCFA, long-chain fatty acid.

For details of diets and procedures, see Tables 1 and 2 and p. 626 .

†Predominantly $16: 1 n-7$.

$\ddagger$ Includes $20: 1 n-11,20: 1 n-9$ and $20: 1 n-7$.

Includes $22: n-13,22: 1 n-11$ and $22: 1 n-9$

II Includes $15: 0$ and $17: 0$

II Includes $14: 1 n-3,15: 1 n-3$ and $18: 1 n-5$.

: $3 n-3,18: 2 n-3$ and $20: 4 n-3$

$\ddagger \mathrm{C}_{14}-\mathrm{C}_{22}$ as defined by Odle (1997). 
Table 4. Fatty acid concentrations of liver total lipids (mg/g tissue DM)*

(Mean values and standard deviations of two aquaria per treatment with fifteen fish per aquarium)

\begin{tabular}{|c|c|c|c|c|c|c|c|c|c|c|c|c|c|c|c|c|}
\hline & \multicolumn{8}{|c|}{ Low-lysine } & \multicolumn{8}{|c|}{ High-lysine } \\
\hline & \multicolumn{4}{|c|}{ Low-fat } & \multicolumn{4}{|c|}{ High-fat } & \multicolumn{4}{|c|}{ Low-fat } & \multicolumn{4}{|c|}{ High-fat } \\
\hline & \multicolumn{2}{|c|}{ Low-carnitine } & \multicolumn{2}{|c|}{ High-carnitine } & \multicolumn{2}{|c|}{ Low-carnitine } & \multicolumn{2}{|c|}{ High-carnitine } & \multicolumn{2}{|c|}{ Low-carnitine } & \multicolumn{2}{|c|}{ High-carnitine } & \multicolumn{2}{|c|}{ Low-carnitine } & \multicolumn{2}{|c|}{ High-carnitine } \\
\hline & Mean & SD & Mean & SD & Mean & SD & Mean & SD & Mean & SD & Mean & SD & Mean & SD & Mean & SD \\
\hline \multicolumn{17}{|l|}{ Fatty acids } \\
\hline $14: 0$ & $6 \cdot 27$ & 0.14 & 8.30 & 0.69 & 7.56 & 0.06 & 7.02 & 0.29 & 8.19 & 0.59 & 8.77 & 0.18 & 11.21 & 1.21 & 9.32 & 0.65 \\
\hline $16: 0$ & 118.75 & 0.30 & $150 \cdot 38$ & 1.98 & 115.98 & $10 \cdot 15$ & 114.61 & 0.9 & 129.96 & 10.52 & 155.97 & 0.46 & 170.32 & $5 \cdot 32$ & 156.58 & 19.00 \\
\hline $18: 0$ & 36.60 & 0.56 & $56 \cdot 22$ & 7.49 & $43 \cdot 76$ & 8.02 & 34.18 & 0.52 & 53.84 & $10 \cdot 28$ & 74.78 & 3.74 & 101.99 & 7.02 & $90 \cdot 89$ & 2.40 \\
\hline $16: 1 \dagger$ & 24.08 & 1.28 & $36 \cdot 11$ & $2 \cdot 17$ & 16.99 & 1.79 & 21.89 & 2.00 & $25 \cdot 23$ & 2.51 & $27 \cdot 76$ & 0.15 & $25 \cdot 37$ & 2.47 & 24.59 & $4 \cdot 26$ \\
\hline $18: 1 n-9$ & 108.44 & 6.96 & 140.46 & 2.47 & 93.00 & $15 \cdot 31$ & 101.62 & 0.78 & $123 \cdot 13$ & 16.97 & 131.52 & $12 \cdot 80$ & 116.83 & 10.98 & 124.37 & 27.95 \\
\hline $18: 1 n-7$ & 6.64 & 0.26 & 8.32 & $1 \cdot 16$ & $6 \cdot 26$ & 0.80 & 7.08 & 0.23 & 6.44 & 0.02 & 6.82 & 0.05 & 7.64 & 0.71 & 6.87 & 0.96 \\
\hline $20: 1 \neq$ & $11 \cdot 11$ & 0.47 & 14.52 & 0.29 & $12 \cdot 71$ & 1.89 & 12.02 & 0.26 & 13.43 & 0.94 & 16.06 & 0.51 & 21.99 & 0.44 & 18.54 & $0.5 \varepsilon$ \\
\hline $22: 1 \S$ & 1.81 & 0.12 & 1.82 & 0.17 & 2.97 & 0.42 & 2.33 & 0.42 & 2.29 & 0.04 & 3.09 & 0.19 & 7.19 & 0.33 & 5.01 & 0.22 \\
\hline $18: 2 n-6$ & $5 \cdot 17$ & 0.93 & 12.55 & $1 \cdot 12$ & 7.48 & 1.22 & 10.43 & 3.49 & 8.56 & 0.01 & 10.07 & 0.47 & 14.67 & 1.72 & $10 \cdot 86$ & 0.02 \\
\hline $20: 2 n-6$ & 0.90 & 0.10 & 1.64 & 0.11 & 1.26 & 0.21 & 1.55 & 0.29 & 1.12 & 0.03 & 1.40 & 0.05 & 1.92 & 0.05 & 1.63 & 0.01 \\
\hline $20: 4 n-6$ & $\operatorname{tr}$ & - & 1.14 & 0.04 & $\operatorname{tr}$ & - & $\operatorname{tr}$ & - & 1.14 & 0.12 & 1.19 & 0.01 & 1.60 & 0.08 & 1.08 & 0.39 \\
\hline $22: 2 n-6$ & $1 \cdot 11$ & 0.19 & 0.99 & 0.25 & 1.01 & 0.19 & $1 \cdot 14$ & 0.02 & 0.68 & 0.01 & 0.80 & 0.12 & 0.93 & 0.19 & $1 \cdot 15$ & 0.45 \\
\hline $18: 3 n-3$ & $\operatorname{tr}$ & - & $\operatorname{tr}$ & - & $\operatorname{tr}$ & - & $\operatorname{tr}$ & - & $\operatorname{tr}$ & - & $\operatorname{tr}$ & - & $2 \cdot 01$ & 0.36 & 1.22 & 0.05 \\
\hline $20: 5 n-3$ & 0.24 & 0.03 & $2 \cdot 71$ & 0.12 & 0.53 & 0.02 & 1.47 & 0.83 & 1.95 & 0.07 & 2.52 & 0.46 & 9.33 & 1.62 & 4.59 & 0.04 \\
\hline $22: 5 n-3$ & 0.34 & 0.03 & 2.05 & 0.09 & 0.78 & 0.27 & 1.30 & 0.51 & 1.37 & 0.04 & 1.90 & 0.31 & $7 \cdot 36$ & 0.20 & $4 \cdot 23$ & 0.52 \\
\hline $22: 6 n-3$ & 0.69 & 0.47 & $15 \cdot 17$ & 0.41 & 2.46 & 1.12 & 8.08 & 3.95 & 10.65 & 0.03 & 14.15 & 1.79 & 39.50 & 1.09 & 27.51 & 3.92 \\
\hline$\Sigma$ SFA\| & 162.68 & 0.97 & $216 \cdot 32$ & 4.73 & 168.91 & 18.88 & $157 \cdot 23$ & 1.71 & 193.65 & 21.42 & 241.44 & 3.50 & 286.68 & 11.02 & 259.02 & 22.05 \\
\hline$\Sigma$ MUFA & $152 \cdot 76$ & 8.34 & $202 \cdot 19$ & 6.31 & 133.05 & $20 \cdot 22$ & $146 \cdot 34$ & 0.79 & 171.62 & $20 \cdot 36$ & 186.55 & 13.05 & 181.22 & 15.09 & 181.09 & 33.53 \\
\hline$\Sigma n-6$ PUFA $^{* *}$ & 8.23 & 1.49 & 19.50 & 1.21 & 11.05 & 1.54 & $15 \cdot 71$ & 4.60 & $13 \cdot 87$ & 0.25 & 15.93 & 0.47 & $21 \cdot 30$ & $2 \cdot 30$ & $17 \cdot 17$ & 0.87 \\
\hline$\Sigma n$-3 PUFAtt & 2.58 & 0.26 & $23 \cdot 18$ & 0.05 & 4.32 & $2 \cdot 24$ & $13 \cdot 37$ & $5 \cdot 88$ & $16 \cdot 66$ & 0.19 & 21.85 & $2 \cdot 71$ & $63 \cdot 30$ & 1.72 & 41.06 & 4.56 \\
\hline$\Sigma$ LCFA㧊 & 326.25 & $9 \cdot 80$ & $461 \cdot 19$ & 3.14 & 317.33 & 44.75 & 332.65 & 9.30 & 395.80 & 43.15 & 465.77 & 14.83 & 552.50 & 8.54 & $498 \cdot 34$ & 52.51 \\
\hline$\sum n-3 / \Sigma n-6$ & 0.32 & 0.09 & 1.19 & 0.07 & 0.38 & 0.15 & 0.93 & 0.13 & $1 \cdot 2$ & 0.01 & 1.37 & 0.21 & 2.99 & 0.24 & 2.40 & 0.39 \\
\hline
\end{tabular}

tr, trace $(<0.5 \mathrm{mg} / \mathrm{g})$; SFA, saturated fatty acid; MUFA, monounsaturated fatty acid; PUFA, polyunsaturated fatty acid; LCFA, long-chain fatty acid.

* For details of diets and procedures, see Tables 1 and 2 and $p .626$.

†Predominantly $16: 1 n-7$.

‡Includes $20: 1 n-11,20: 1 n-9$, and $20: 1 n-7$.

§Includes $22: n-13,22: 1 n-11$ and $22: 1 n-9$

II Includes $15: 0$ and $17: 0$.

I Includes $14: 1 n-3,15: 1 n-3$ and $18: 1 n-5$.

${ }^{* *}$ Includes $16: 3 n-6$ and $20: 3 n-6$

$\neq \mathrm{C}_{14}-\mathrm{C}_{22}$ as defined by Odle (1997). 
Carnitine tended to decrease the concentration of the saturated fatty acids, mainly 16:0, when fish were fed lowlysine diets. Concentrations of $n-3$ and $n-6$, however, were elevated by the intake of high-fat diets $(P<0.05)$. Within the low-lysine groups, high-fat supplements caused an increase of $n-3$ and $n-6$ PUFA deposition respectively, from 38.8 $(13.7 \%)$ to $58.3 \mathrm{mg} / \mathrm{kg}(18.1 \%)$ and from $24 \cdot 1(8.5 \%)$ to $36 \cdot 1 \mathrm{mg} / \mathrm{kg}(11 \cdot 2 \%)$ over the feeding trial.

In contrast to muscle, liver of fish fed high-carnitine diets showed an increase in fatty acid concentration, regardless of dietary lysine and fat level. The fatty acids $18: 2 n-6$, $20: 5 n-3,22: 6 n-3$ were the primary fatty acids affected (Table 4). Dietary carnitine supplements severely raised $n-3$ PUFA liver concentration from $2.6(0.8 \%)$ to $23.2 \mathrm{mg} / \mathrm{g}$ $(5 \%)$ when fish were fed $90 \mathrm{~g}$ fat and from $2.3(0.7 \%)$ to $13.4 \mathrm{mg} / \mathrm{g}(4 \%)$ when fed $190 \mathrm{~g}$ fat $(P<0.005)$, and interactions were also observed (Table 5). The elevation of $n$-3 PUFA concentrations were associated with a 20-fold increase of $22: 6 n-3$ and 10-fold increase of $20: 5 n-3$ concentrations $(P<0 \cdot 005)$. Similarly, high-carnitine intake increased $18: 2 n-6$ concentration 2 -fold $(P<0 \cdot 05)$. Highcarnitine level coupled with low-fat level increased deposition of the saturated and monounsaturated fatty acids.

\section{Whole-body fatty acid balance}

Effects of dietary treatments on linoleic acid (18:2n-6), eicosapentanoic acid (20:5n-3) and docosahexanoic acid (22: $6 n-3)$ balance in the whole body of the juvenile African catfish are presented in Table 6. The whole-body fatty acid balance showed that dietary carnitine and fat supplements clearly affected accumulation and disappearance of $20: 5 n-3,18: 2 n-6$ and $22: 6 n-3$. Fish fed highlysine supplements accumulated less $18: 2 n-6$ in their body than the low-lysine animals. In conclusion, dietary carnitine and fat supplements significantly influenced the whole-body concentrations of linoleic acid and interactions between lysine and fat supplements were observed.

The disappearance of $20: 5 n-3$ was by far the highest among the PUFA, ranging from 52.5 to $65.3 \%$. Dietary fat and carnitine supplements also affected accumulation of $20: 5 n-3$ in the whole body of the African catfish. Within the low-lysine-low-fat groups, 533.4 and $535 \mathrm{mg} 20: 5 n-3$ were consumed respectively by the fish fed the low- and high-carnitine diets, $202(37.9 \%)$ and $197.5 \mathrm{mg}(36.9 \%)$ accumulated, and $331.3(62.1 \%)$ and $337.5 \mathrm{mg}(63.1 \%)$ disappeared. Carnitine supplements slightly increased the whole-body disappearance of $22: 6 n-3$. Within the lowlysine-low-fat groups, $640 \cdot 3$ and $636 \cdot 8 \mathrm{mg} 22: 6 n-3$ were consumed respectively by fish fed low- and high-carnitine diets, $581(90.9 \%)$ and $569.7 \mathrm{mg}(89.5 \%)$ accumulated, and $58.5(9.1 \%)$ and $67.1 \mathrm{mg}(10.5 \%)$ disappeared. In general, fish fed $190 \mathrm{~g}$ fat $/ \mathrm{kg}$ diet showed reduced accumulation of $n-6$ and $n-3$ long-chain PUFA compared with fish fed $90 \mathrm{~g}$ $\mathrm{fat} / \mathrm{kg}$ diet.

\section{Discussion}

\section{African catfish}

The African catfish is a scaleless fish with an eel-like body shape and a slightly depressed head. African catfish are airbreathers, omnivores, and normally found in turbid waters. It is farmed mainly in Africa and Europe (Huisman \& Richter, 1987), although it is now also receiving attention in India, China and some East European countries, and also has recently been introduced into Brazil (Hecht et al. 1996). It was chosen as a model species because it is a fish easy to farm (robust, rapid growth, closing live-cycle) and because of its well-documented nature of growth and body

Table 5. Three-way ANOVA of individual fatty acid concentration of liver total lipids $†$

\begin{tabular}{|c|c|c|c|c|c|c|}
\hline & \multicolumn{6}{|c|}{$\begin{array}{c}\text { Statistical significance of effect } \\
\text { (three-way ANOVA) } \neq\end{array}$} \\
\hline & Carnitine & Lysine & Fat & Carnitine $\times$ lysine & Lysine $\times$ fat & Carnitine $\times$ fat \\
\hline \multicolumn{7}{|l|}{ Fatty acids } \\
\hline $14: 0$ & NS & * & * & * & * & * \\
\hline $16: 0$ & $\star \star$ & * & NS & NS & * & * \\
\hline $18: 0$ & NS & * & $*$ & NS & * & * \\
\hline $16: 1 \S$ & * & NS & * & * & * & * \\
\hline $18: 1 n-9$ & * & * & * & NS & NS & NS \\
\hline $18: 1 n-7$ & NS & NS & NS & * & * & NS \\
\hline $20: 1$ & NS & * & * & NS & * & * \\
\hline $22: 1$ & * & * & * & NS & * & * \\
\hline $18: 2 n-6$ & * & * & * & * & * & * \\
\hline $18: 3 n-6$ & NS & * & NS & NS & * & NS \\
\hline $20: 2 n-6$ & * & * & * & * & * & * \\
\hline $20: 4 n-6$ & * & * & NS & * & * & * \\
\hline $22: 2 n-6$ & NS & NS & NS & NS & NS & NS \\
\hline $20: 5 n-3$ & NS & ** & $\star *$ & NS & $\star \star \star *$ & $\star \star \star *$ \\
\hline $22: 5 n-3$ & NS & ** & ** & * & *** & *** \\
\hline $22: 6 n-3$ & * & ** & * & * & $\star * * *$ & $\star \star * *$ \\
\hline
\end{tabular}

${ }^{\star} P<0.05,{ }^{* *} P<0.01,{ }^{* * *} P<0.005$.

†For details of diets and procedures, see Tables 1 and 2 and p. 626

$\ddagger$ A three-way interaction was not observed.

$\S$ Predominantly $16: 1 n-7$. 
Table 6. Effects of dietary treatments on linoleic acid (18:2n-6), eicosapentanoic acid $(20: 5 n-3)$ and docosahexanoic acid (22: $6 n-3)$ balance in the whole-body (wet weight basis) of the African catfish (Clarias gariepinus Burchell)* juvenile

(Mean values for two aquaria per treatment with fifteen fish per aquaria)

\begin{tabular}{|c|c|c|c|c|c|c|c|c|}
\hline & \multicolumn{4}{|c|}{ Low-lysine } & \multicolumn{4}{|c|}{ High-lysine } \\
\hline & \multicolumn{2}{|c|}{ Low-fat } & \multicolumn{2}{|c|}{ High-fat } & \multicolumn{2}{|c|}{ Low-fat } & \multicolumn{2}{|c|}{ High-fat } \\
\hline & Low carnitine & High carnitine & Low carnitine & High carnitine & Low carnitine & High carnitine & Low carnitine & High carnitine \\
\hline Duration of feeding trial (d) & 74 & 74 & 74 & 74 & 53 & 53 & 53 & 53 \\
\hline \multicolumn{9}{|l|}{$18: 2 n-6$} \\
\hline $\begin{array}{l}\text { Intake (mg) } \\
\text { Body content (mg) }\end{array}$ & \multicolumn{7}{|c|}{ Body content (mg) } & $463 \cdot 4$ \\
\hline Initial & $7 \cdot 3$ & $7 \cdot 8$ & $7 \cdot 6$ & $7 \cdot 3$ & $7 \cdot 7$ & $7 \cdot 8$ & $8 \cdot 2$ & $7 \cdot 5$ \\
\hline Final & $492 \cdot 0$ & 504.9 & 883.8 & $772 \cdot 0$ & $419 \cdot 4$ & 424.7 & $466 \cdot 8$ & $416 \cdot 7$ \\
\hline Accumulation (mg) & $484 \cdot 7$ & $497 \cdot 2$ & $876 \cdot 1$ & $764 \cdot 6$ & $411 \cdot 7$ & $416 \cdot 8$ & $458 \cdot 5$ & $409 \cdot 2$ \\
\hline$\% 18: 2 n-6$ intake & $92 \cdot 2$ & $90 \cdot 8$ & $87 \cdot 6$ & $82 \cdot 7$ & $76 \cdot 9$ & $77 \cdot 9$ & $93 \cdot 0$ & $88 \cdot 3$ \\
\hline Disappearance $(\mathrm{mg}) \S$ & $40 \cdot 7$ & $50 \cdot 7$ & $123 \cdot 8$ & 159.5 & $123 \cdot 4$ & $118 \cdot 1$ & $34 \cdot 3$ & $54 \cdot 2$ \\
\hline$\%$ Intake & $7 \cdot 8$ & $9 \cdot 2$ & $12 \cdot 4$ & $17 \cdot 3$ & $23 \cdot 1$ & $22 \cdot 1$ & $7 \cdot 0$ & $11 \cdot 7$ \\
\hline \multicolumn{9}{|l|}{$20: 5 n-3$} \\
\hline Intake (mg) & $533 \cdot 4$ & $535 \cdot 0$ & $894 \cdot 3$ & $810 \cdot 8$ & $453 \cdot 2$ & $462 \cdot 2$ & $857 \cdot 4$ & $773 \cdot 9$ \\
\hline \multicolumn{9}{|l|}{ Body content (mg) } \\
\hline Initial & $7 \cdot 3$ & $7 \cdot 8$ & $7 \cdot 7$ & $7 \cdot 4$ & $7 \cdot 8$ & $7 \cdot 9$ & 8.3 & $7 \cdot 6$ \\
\hline Final & $209 \cdot 4$ & $205 \cdot 4$ & $354 \cdot 6$ & 288.5 & $209 \cdot 6$ & 227.5 & $370 \cdot 1$ & $278 \cdot 8$ \\
\hline Accumulation (mg) & $202 \cdot 0$ & $197 \cdot 5$ & $346 \cdot 9$ & $281 \cdot 1$ & $201 \cdot 8$ & $219 \cdot 6$ & $361 \cdot 8$ & $271 \cdot 3$ \\
\hline$\% 20: 5 n-3$ intake & 37.9 & 36.9 & $38 \cdot 8$ & $34 \cdot 7$ & $44 \cdot 5$ & $47 \cdot 5$ & $42 \cdot 2$ & $35 \cdot 1$ \\
\hline Disappearance $(\mathrm{mg}) \S$ & $331 \cdot 3$ & 337.5 & $547 \cdot 3$ & 529.8 & 251.4 & $242 \cdot 6$ & $495 \cdot 6$ & $502 \cdot 6$ \\
\hline$\%$ Intake & $62 \cdot 1$ & $63 \cdot 1$ & $61 \cdot 2$ & $65 \cdot 3$ & $55 \cdot 5$ & $52 \cdot 5$ & $57 \cdot 8$ & $64 \cdot 9$ \\
\hline \multicolumn{9}{|l|}{$22: 6 n-3$} \\
\hline Intake (mg) & $640 \cdot 3$ & $636 \cdot 8$ & $1296 \cdot 6$ & $1177 \cdot 9$ & $604 \cdot 3$ & $616 \cdot 3$ & $1243 \cdot 3$ & $1106 \cdot 1$ \\
\hline \multicolumn{9}{|l|}{ Body content (mg) } \\
\hline Initial & $23 \cdot 4$ & $25 \cdot 0$ & 24.5 & $23 \cdot 6$ & $24 \cdot 8$ & $25 \cdot 1$ & $26 \cdot 5$ & $24 \cdot 1$ \\
\hline Final & $605 \cdot 2$ & $594 \cdot 7$ & $1012 \cdot 2$ & $885 \cdot 3$ & $558 \cdot 2$ & $573 \cdot 2$ & $909 \cdot 8$ & $786 \cdot 6$ \\
\hline Accumulation (mg) & $581 \cdot 8$ & $569 \cdot 7$ & $987 \cdot 7$ & $861 \cdot 6$ & 533.5 & 548.0 & $883 \cdot 3$ & $762 \cdot 5$ \\
\hline$\% 22: 6 n-3$ intake & $90 \cdot 9$ & 89.5 & $76 \cdot 2$ & $73 \cdot 1$ & $88 \cdot 3$ & 88.9 & $71 \cdot 0$ & 68.9 \\
\hline Disappearance $(\mathrm{mg}) \S$ & 58.5 & $67 \cdot 1$ & 308.9 & $316 \cdot 3$ & $70 \cdot 8$ & $68 \cdot 3$ & $360 \cdot 0$ & $343 \cdot 6$ \\
\hline$\%$ Intake & $9 \cdot 1$ & $10 \cdot 5$ & $23 \cdot 8$ & $26 \cdot 9$ & $11 \cdot 7$ & $11 \cdot 1$ & $29 \cdot 0$ & $31 \cdot 1$ \\
\hline
\end{tabular}

*Body weight $100-130 \mathrm{~g}$.

†For details of diets and procedures, see Tables 1 and 2 and p. 626

$\S$ Excludes excretion. 
composition, which enables a better evaluation of the results.

\section{Performance}

Since all treatment groups consumed the same amount of feed, differences in SGR in some groups were reflected in differences in FCR, which varied between 1.0 and $1.6 \mathrm{~g} / \mathrm{g}$. Low-lysine-high-fat-low-carnitine and high-lysine-highfat-high-carnitine groups grew $2 \cdot 3$ and $3.3 \%$ body weight/d respectively. In those situations, the total feed allowance was consumed in different periods, i.e. 74 v. $53 \mathrm{~d}$.

Extra lysine supplements to low-lysine diets improved SGR and decreased FCR $(P<0 \cdot 05)$. Since juvenile catfish have a high potential for growth and high food intake, it seems that amino acid imbalance may have a larger impact
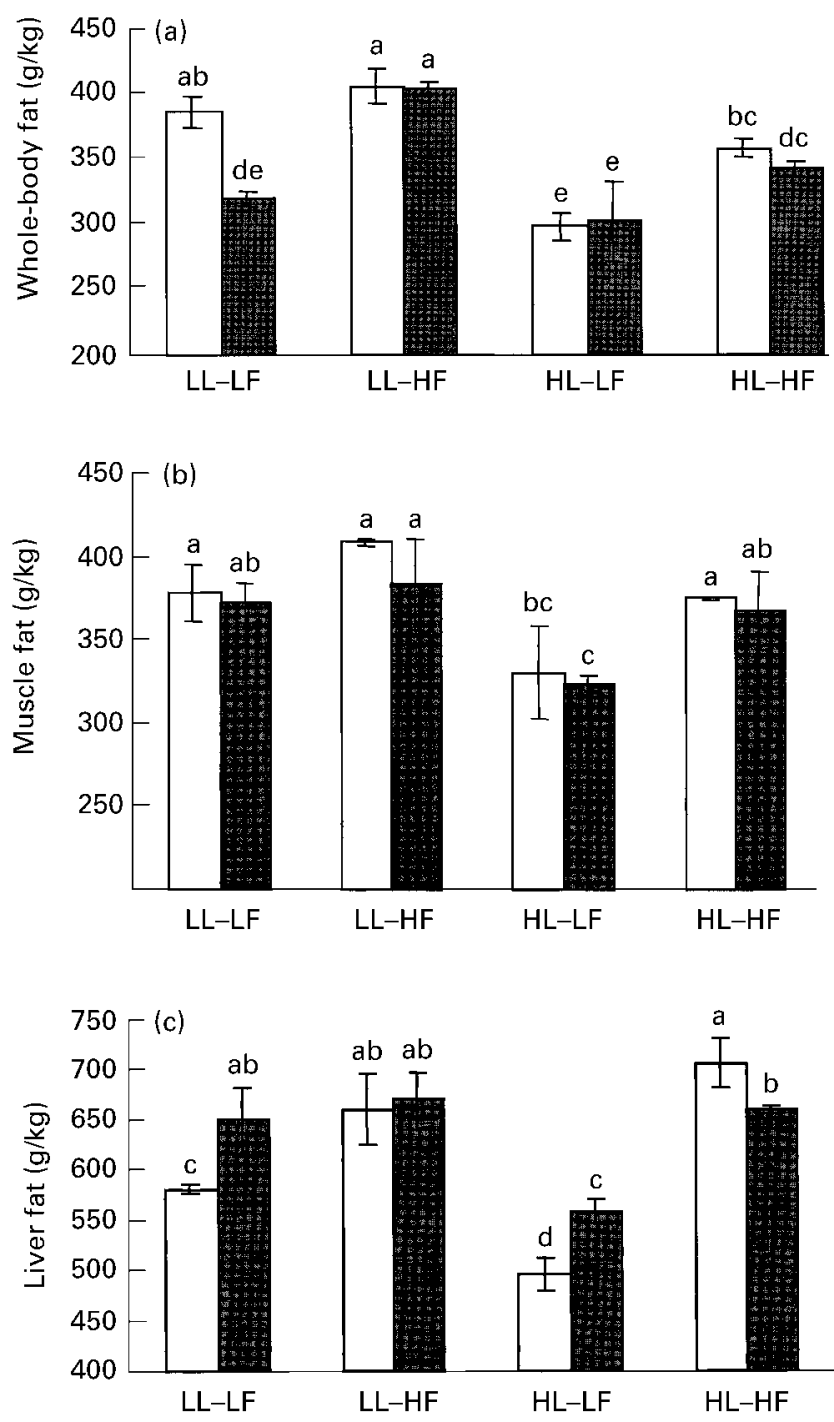

on growth depression and feed conversion efficiencies (Conceição et al. 1998a) than in adult fish. Fish receiving low-lysine diets showed higher HSI than fish fed the highlysine diets $(P<0 \cdot 005)$. These animals had increased fat and decreased protein deposition in the liver (Fig. 4). In addition, Conceição et al. (1998b) showed that amino acid imbalances between the dietary and the fish amino acid profiles lead to an increase in lipid deposition. Several other studies have also shown supplementation of extra lysine to diets increased protein and reduced fat in tissue of catfish (Munsiri \& Lovell, 1993; Li \& Robinson, 1998). It has been proposed that fish fed lower dietary fat:carbohydrate ratio tend to produce higher HSI (Higgs et al. 1992) and lower growth (Erfanullah, 1998).

The present study showed that dietary carnitine supplementation in low-carnitine diets slightly affected
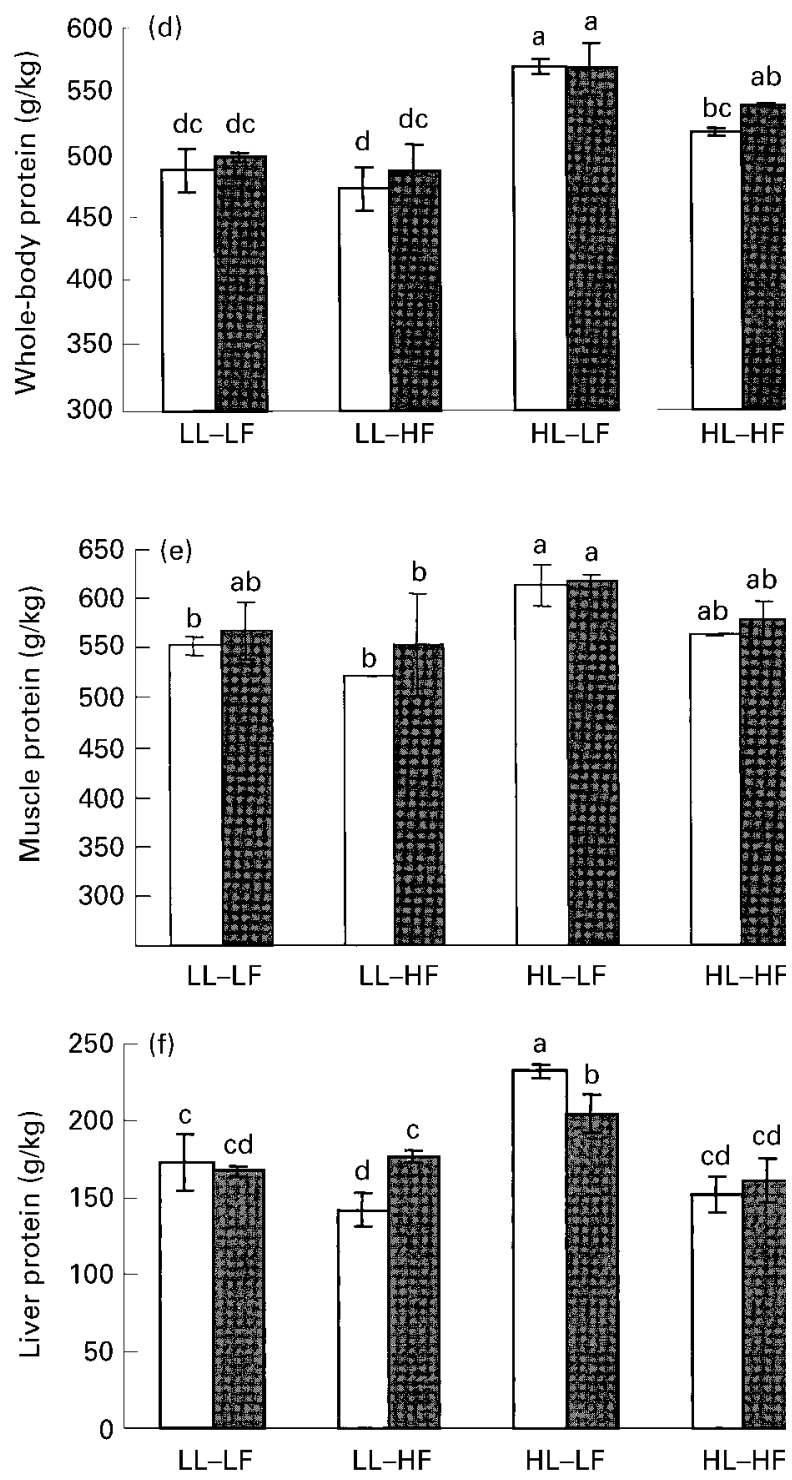

Fig. 4. Effect of feeding different experimental diets on (a, b, c) fat and (d, e, f) protein content in whole-body, muscle and liver tissues of African catfish (Clarias gariepinus Burchell). For details of diets and procedures, see Tables 1 and 2 and p. 626. LL, low-lysine; HL, high-lysine; LF, low-fat; HF, high-fat. $\square$, Low-carnitine; $\square$, high-carnitine. Values are means for two aquaria per treatment with twelve fish per treatment, with standard deviations shown by vertical bars. ${ }^{a, b, c, d, e}$ Mean values with unlike superscript letters were significantly different (ANOVA, $P<0.05)$. 
SGR and FCR in African catfish. Our results did not support those of Torreele et al. (1993), who clearly found faster and more efficient growth with increased levels of dietary carnitine. Torreele et al. (1993) fed commercial diets with higher crude protein levels compared with our present study. In addition, Torreele et al. (1993) studied growing animals from 5 to about $30 \mathrm{~g}$, while in the present experiment, the initial fish size was already $23 \mathrm{~g}$.

Growth rates (per unit of body mass) decrease as fish increase in size therefore a dietary carnitine deficiency may be more easily expressed at small fish size. Our results are in agreement with several other studies (Rodehutscord, 1995; Chatzifotis et al. 1996; Harpaz et al. 1999), that observed some effect of carnitine on growth and body composition. The absence of a clear effect of carnitine supplementation on weight gain of fish fed low-lysine diets suggests that lowlysine level in our present study did not impair the carnitine biosynthesis capacity. It may also be that lysine deficiency overrules any effect of carnitine.

\section{Tissue carnitine content}

Dietary lysine and methionine are required for the biosynthesis of carnitine (Broquist, 1997). Dietary lysine deficiency is therefore associated with reduced total body carnitine. It has been reported that endogenous carnitine synthesis alone may not be sufficient to meet the energy demands in fast growing juvenile animals (Rebouche \& Seim, 1998; Bamji, 1984). Carnitine homeostasis in animals is maintained by a combination of absorption of carnitine from the diet, a modest rate of biosynthesis, and an efficient reabsorption of carnitine. Thus, fish may become carnitinedeficient if carnitine and/or its precursors are not present in the diet.

In the present study, high-carnitine groups accumulated significantly more free- and acyl-carnitine than lowcarnitine groups. This suggests that dietary carnitine was absorbed and entered in the intermediary metabolism. Carnitine was stored mainly in the muscle tissue. Muscle free-carnitine was lower $(P<0.01)$ in fish fed high-lysine diets. No differences in acyl-carnitine level were observed. Three alternatives are suggested as explanation. First, highlysine levels may lead to some extent to a decrease in carnitine biosynthesis. Davis et al. (1993) also showed that rats fed high-lysine diet had lower plasma carnitine concentration than did controls. Second, this depression may be caused by increased excretion in kidney. Third, being a carnitine storage site implies that muscle carnitine may be transported to other body tissues during high metabolic demands.

In contrast to muscle, liver free-carnitine content was substantially increased and acyl-carnitine decreased when fish were fed high-lysine diets compared with the low-lysine groups. High-fat-high-carnitine groups showed lower free carnitine:acyl-carnitine ratio compared with low-fat-lowcarnitine group. This decline was caused by an increase in the carnitine ester content, thus indicating an increase in carnitine mobilisation towards lipid oxidation.

\section{Fatty acid concentrations}

Overall, the decrease of muscle fatty acid concentrations corresponds well with the decrease in muscle total fat content (Fig. 4). It is feasible to speculate that this reduction was due to a decrease in muscle $\mathrm{C}_{14}-\mathrm{C}_{22}$ fatty acid concentrations. Few changes in muscle fatty acid concentrations were observed in high-carnitine fish compared with low-carnitine animals.

High-carnitine supplements have severely increased PUFA concentration, in particular $22: 6 n-3$ and $20: 5 n-3$, in the livers of fish fed low-lysine diets. Recent evidence suggests that $22: 6 n-3$ and $20: 5 n-3$ appear to be synthesised in liver mitochondria by the recently elucidated fatty acid desaturases for which carnitine is an essential cofactor (Infante \& Huszagh, 2000; Wynn \& Ratledge, 2000). Our current results showed that feeding extra carnitine to low-lysine-low-fat-fed fish may overrule the repression of PUFA biosynthesis and/or fatty acid desaturation and elongation. Muscle fat content was not significantly affected by high-carnitine supplements. High-carnitine lowered whole-body fat content and increased the protein:fat ratio only in low-lysine-low-fat groups (Fig. $4, P<0.05$ ). The latter findings and the fact that the great majority of lipids in catfish are deposited in intraperitoneal fat indicates that the increase in liver fatty acid concentrations is derived from intraperitoneal tissue. However, we did not measure intraperitoneal fat in the present study.

\section{Whole-body fatty acid balance}

To the best of our knowledge, this is the first study to report the effect of carnitine on fatty acid balance in fish. Without tracers, the quantitative method can be utilised to determine the partitioning of dietary fatty acids between accumulation, and disappearance (or apparent oxidation) in response to altered nutrient and energy demands. The results showed that fatty acid disappearance was stimulated significantly by high-carnitine and high-fat supplements in the diet. Fatty acid oxidation was assumed to be equal to fatty acid disappearance. We assumed however complete digestion of fatty acids. This may have resulted in overestimation of lipid oxidation rate. In addition, the fatty acid method assumes that PUFA disappearance can be calculated from measurements of fatty acid intake and accumulation. Conversion of fatty acids like $20: 5 n-3$ to $22: 6 n-3$ may have occurred. Thus, this method only gives some references to fatty acid balance.

In conclusion, although the present study indicated a limited benefit of dietary carnitine supplementation on growth performance, our findings support the hypothesis that dietary carnitine can enhance the mobilisation of long-chain fatty acids towards oxidation.

\section{Implications}

Endogenous triacylglycerols represent an important source of fuel during physical activity, whereas triacylglycerol oxidation increases progressively during exercise. The oxidation rate of lipids is determined by energy requirements of working muscles and by the availability of 
free-carnitine delivery to muscle mitochondria. Carnitine has been thoroughly investigated for its role in exercise performance in human subjects and terrestrial animals (Souffleux, 1994; Janssens et al. 1998; Kraemer \& Volek, 2000; Sachan \& Hongu, 2000). The effect of dietary carnitine supplements on the energy metabolism of fish during a physical stress (i.e. exhaustive swimming) is however unknown, and therefore it is a new and interesting subject for future research.

\section{Acknowledgements}

We acknowledge Tino Leffering and Dick Bongers for their excellent technical assistance during the fatty acid analysis. We are greatful to Mr Richard Sasse representing Lonza Group Ltd. for financing the carnitine analysis and for the generous supplying of Carniking ${ }^{\circledR}$, Professor Johein Harmeyer for the carnitine analyses reported here, and Professor Martin Verstegen for editorial assistance. This study was supported by the Brazilian National Research Council (CNPq), Brazil, no. 200298/95.0. The results presented are part of the PhD thesis of R.O.A. Ozório.

\section{References}

Bamji MS (1984) Nutritional and health implications of lysine carnitine relationship. World Review of Nutrition and Dietetics 44, 185-211.

Becker K, Schreiber S, Angoni C \& Blum R (1999) Growth performance and feed utilization response of Oreochromis niloticus $\times$ Oreochromis aureus hybrids to L-carnitine measured over a full fattening cycle under commercial conditions. Aquaculture 174, 313-322.

Bilinski E \& Jonas REE (1970) Effects of coenzyme A and carnitine on fatty acid oxidation by rainbow trout mitochondria. Canadian Journal of Fisheries and Aquatic Science 27, 857-864.

Brafield AE (1985) Laboratory studies of energy budget. In Fish Energetics: New Perspectives, pp. 257-281 [P Taylor and P Calow, editors]. London, UK: Croom Helm.

Brooks DE \& McIntosh JE (1975) Turnover of carnitine by rat tissues. Biochemical Journal 148, 439-445.

Broquist HP (1997) Memories of microbes and metabolism. Annual Review of Nutrition 17, 1-18.

Cederblad G \& Lindstedt S (1976) Metabolism of labeled carnitine in the rat. Archives of Biochemistry Biophysics 175, 173-180.

Chatzifotis S, Takeushi T \& Seikai T (1995) The effect of dietary carnitine on growth performance and lipid composition in Red Sea bream fingerlings. Fisheries Science 61, 1004-1008.

Chatzifotis S, Takeushi T \& Seikai T (1996) The effect of dietary carnitine supplementation on growth of Red Sea bream (Pagrus major ) fingerlings at two levels of dietary lysine. Aquaculture 147, 235-248.

Christiansen RZ \& Bremer J (1988) Acetylation of Tris(hydroxymethyl) amino-methane (Tris) and Tris derivatives by carnitine acetyltransferase. FEBS Letters 86, 99-102.

Conceição LEC, Ozório ROA, Suurd EA \& Verreth JAJ (1998a) Amino acid profiles and amino acid utilization in larval African catfish (Clarias gariepinus): effects of ontogeny and temperature. Fish Physiology and Biochemistry 19, 43-57.

Conceição LEC, Verreth JAJ, Verstegen MWA \& Huisman EA (1998b) preliminary model for dynamic simulation of growth in fish larvae: application to the African catfish (Clarias gariepinus) and turbot (Scophthalmus maximus). Aquaculture 163, 215-235.

Cunnane SC \& Yang J (1995) Zinc deficiency impairs whole-body accumulation of polyunsaturates and increases the utilization of [1-14 C]-linoleate for de novo lipid synthesis in pregnant rats. Canadian Journal Physiology Pharmacology 73, 1246-1252.

Davis AT, Kruggel EM \& Randall S (1993) Excess of dietary lysine increases skeletal muscle and plasma trimethyllysine in rats. Journal of Nutrition 6, 1109-1116.

Erfanullah AKJ (1998) Effect of dietary carbohydrate-to-lipid ratio on growth and body composition of walking catfish (Clarias batrachus ). Aquaculture 161, 159-168.

Gaylord TG \& Gatlin DM (2000) Dietary lipid level but not L-carnitine affects growth performance of hybrid striped bass (Morone chrysops $\times$ M. saxatilis). Aquaculture 190, 237-246.

Gropp JM, Schumacher A \& Schweigert FJ (1994) Recent research in vitamin nutrition with special emphasis to vitamin $A, \beta-$ carotene and L-carnitine. In Proceedings of the Meeting of the Arkansas Nutrition Conference, pp. 124-134. Fayetteville, AR: Arkansas Poultry Federation.

Harpaz S, Becker K \& Blum R (1999) The effect of dietary L-carnitine supplementation on cold tolerance and growth of the ornamental cichlid fish (Pelvicachromis pulcher) - preliminary results. Journal of Thermal Biology 24, 57-62.

Hecht T, Oellermann L \& Verheust L (1996) Perspective on clariid catfish culture in Africa. In The Biology and Culture of Catfishes [M Legendre and JP Proteau, editors]. Aquatic Living Resources 9, 197-206.

Heo K, Odle J, Han IK, Cho W, Seo S, van Heugten E \& Pilkington DH (2000) Dietary L-carnitine improves nitrogen utilization in growing pigs fed low energy, fat-containing diets. Journal of Nutrition 130, 1809-1814.

Higgs DA, Dosanjh BS, Uin LM, Himick BA \& Eales JG (1992) Effects of dietary-lipid and carbohydrate-levels and chronic 3,5,3'-triiodo-L-thyronine treatment of growth, appetite, food and protein-utilization and body composition of immature rainbow-trout, Oncorhynchus-mykiss, at low-temperature. Aquaculture 105, 175-190.

Huisman EA \& Richter CJJ (1987) Reproduction, growth, health control and aquaculture potential of the African catfish, Clarias gariepinus (Burchell 1822). Aquaculture 63, 1-14.

Infante JP \& Huszagh VA (2000) Secondary carnitine deficiency and impaired docosahexaenoic $(22: 6 n-3)$ acid synthesis: a common denominator in the pathophysiology of diseases of oxidative phosphorylation and beta-oxidation. FEBS Letters 469, $1-5$.

International Organization for Standardization ISO 5483 (1979) Animal Feeding Stuffs - Determination of Nitrogen Content and Calculation of Crude Protein Content, Geneva: ISO.

International Organization for Standardization ISO 5984 (1978) Animal Feeding Stuffs - Determination of Crude Ash, Geneva: ISO.

International Organization for Standardization ISO 6496 (1983) Animal Feeding Stuffs - Determination of Moisture Content, Geneva: ISO.

Janssens GPJ, Buyse J, Seynaeve M, Decuypere E \& De Wilde R (1998) The reduction of heat production in exercising pigeons after L-carnitine supplementation. Poultry Science 77, 578-584.

Jayaprakas V \& Sambhu C (1996) Growth response of white prawn, Penaeus indicus, to dietary L-carnitine. Asian Fisheries Science 9, 209-219.

Ji H, Bradley TM \& Tremblay GC (1996) Atlantic salmon (Salmo salar) fed L-carnitine exhibit altered intermediary metabolism and reduced tissue lipid, but no change in growth rate. Journal of Nutrition 126, 1937-1950.

Kraemer WJ \& Volek JS (2000) L-Carnitine supplementation for 
the athlete: a new perspective. Annals of Nutrition and Metabolism 44, 88-89.

Krajcovicova-Kudlackova M, Simoncic R, Bederova A, Babinska $\mathrm{K} \&$ Beder I (2000) Correlation of carnitine levels to methionine and lysine intake. Physiological Research 49, 399-401.

Lepage G \& Roy CC (1984) Improved recovery of fatty acid through direct transesterification without prior extraction or purification. Journal of Lipid Research 25, 1391-1396.

Li MH \& Robinson EH (1998) Effects of supplemental lysine and methionine in low protein diets on weight gain and body composition of young channel catfish Ictalurus punctatus. Aquaculture 163, 297-307.

Munsiri P \& Lovell RT (1993) Comparison of satiate and restricted feeding of Channel catfish with diets of varying protein quantity in production ponds. Journal of the World Aquaculture Society 24, 459-465.

Odle J (1997) New insights into the utilization of medium-chain triglycerides by the neonate: observations from a piglet model. Journal of Nutrition 127, 1061-1067.

Rabie MH \& Szilagyi M (1998) Effects of L-carnitine supplementation of diets differing in energy levels on performance, abdominal fat content, and yield and composition of edible meat of broilers. British Journal of Nutrition 80, 391-400.

Rebouche CJ \& Seim H (1998) Carnitine metabolism and its regulation in microorganisms and mammals. Annual Review of Nutrition 18, 39-61.

Robinson EH, Wilson RP \& Poe WE (1980) Re-evaluation of the lysine requirement and lysine utilization by fingerling channel catfish. Journal of Nutrition 110, 2313-2316.

Rodehutscord M (1995) Effects of supplemental dietary L-carnitine on the growth and body composition of rainbow trout (Oncorhynchus mykiss) fed high-fat diets. Journal of Animal Physiology and Animal Nutrition 73, 276-279.

Sachan DL \& Mynatt RL (1993) Wheat gluten-based diet retarded ethanol metabolism by altering alcohol-dehydrogenase and not carnitine status in adult rats. Journal of the American College of Nutrition 12, 170-175.

Sachan DS \& Hongu N (2000) Increases in $\mathrm{VO}_{2}$ max and metabolic markers of fat oxidation by caffeine, carnitine, and choline supplementation in rats. Journal of Nutritional Biochemistry 11, $521-526$.

Souffleux G (1994) Benefit of using Rossovet carnitine for horses in preparation for amateur carriage-racing. Pratique Vétérinaire Équine 26, 241-248.

Torreele E, van der Sluiszen A \& Verreth J (1993) The effect of dietary L-carnitine on the growth performance in fingerlings of the African catfish (Clarias gariepinus) in relation to dietary lipid. British Journal of Nutrition 69, 289-299.

Uys W (1989) Aspects of the nutritional physiology and dietary requirements of juvenile and adult sharptooth catfish, Clarias gariepinus (Pisces: Clariidae). PhD Thesis, Rhodes University.

Van Kempen TATG \& Odle J (1995) Carnitine affects octanoate oxidation to carbon dioxide and dicarboxylic acids in colostrumdeprived piglets: In vivo analysis of mechanisms involved based on CoA- and carnitine-ester profiles. Journal of Nutrition 125, $238-250$.

Wynn JP \& Ratledge C (2000) Evidence that the rate-limiting step for the biosynthesis of arachidonic acid in Mortierella alpina is at the level of the $18: 3$ to $20: 3$ elongase. Microbiology-UK 146, 2325-2331. 